Matematikai Közlemények

III. kötet, 2015

doi:10.20312/dim.2015.06

\title{
Egy érdekes térképi vetület matematikai és csillagászati alkalmazásai - folytatás
}

\author{
Péntek Kálmán \\ NymE TTK Matematika és Fizikai Intézet \\ pentek@ttk.nyme.hu
}

\begin{abstract}
Összefoglaló. A dolgozat a szférikus csillagászattal foglalkozik és bemutat egy, a Nap égbolton történő mozgását szemléltető forgatható korongot (univerzális asztrolábiumot). A készülék első verzióját Philippe de la Hire (1640-1718) alkotta meg 1701-ben. A készülék modern és átdolgozott változatát e cikk szerzője készítette el. Azokat a legfontosabb csillagászati és földrajzi feladatokat érintjük, amelyek ezen eszközzel könnyen megoldhatóak.
\end{abstract}

\begin{abstract}
In the paper we present the spherical astronomy tool - called rotable daily arc plate (universal astrolabe) - which represents the moving of the Sun in the sky. The first version of this tool was made by Philippe de la Hire (1640-1718) in 1701. The modern and improved version was designed by the author of this paper. We present the most important astronomical and geographical processes, which we can easily solve by the using of this tool.
\end{abstract}

\section{Bevezetés}

Ez a dolgozat a szerzőnek a Dimenziók II. kötetében 2014-ben ugyanilyen címen megjelent munkájának szerves folytatása (PÉNTEK, 2014). Az ott bemutatott Philippe de la Hire-féle vetületi rendszeren alapuló univerzális asztrolábium vizsgálatát és elemzését tartalmazza. A vizsgált vetület további tulajdonságait SNYDER-VOXLAND (1989) müve, az asztrolábiumok különböző típusait HOLLANDER (1999) és MORRISON (2010) monográfiájában találhatjuk. Tárgyalásunk során bemutatjuk a vizsgált asztrolábium korongjának egy érdekes alkalmazását, amikor egy egyszerü kiegészítéssel napóraként alkalmazva néhány perc pontossággal meghatározhatjuk a valódi napidőt, amelynek pedig egyszerü átalakításával megkaphatjuk a karóránk által is mutatott közép-európai zónaidőt.

\subsection{A Philippe de la Hire vetületén alapuló csillagászati korong}

La Hire előző dolgozatban (PÉNTEK, 2014) ismertetett vetületén alapuló készülék két rétegből álló, lapos korong alakú taneszköz, amelynek rétegei a két körlemez középpontján átmenö, a korongok síkjára merőleges tengely körül elforgatható módon vannak összekapcsolva.

A felső réteg merev fóliából készült, átlátszó, rajta megtalálható az éggömb Philippe de la Hire ekvatoriális vetülete hálózatának képe arról az égi egyenlítői zónáról, amely mentén a Nap évi látszólagos mozgását végzi. Mivel a Föld tengelyferdesége jó közelítéssel $23^{\circ} 30^{\prime}$,

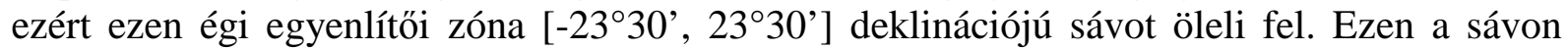
belül megjelöltük azokat a Nappályákat, amelyek mentén a tavaszi napéjegyenlőségtől indulva a Nap jó közelítéssel 10-10 nap elteltével végighalad. Ezek értékeit és a hozzátartozó dátumokat a 1. táblázat tartalmazza (1. ábra). 


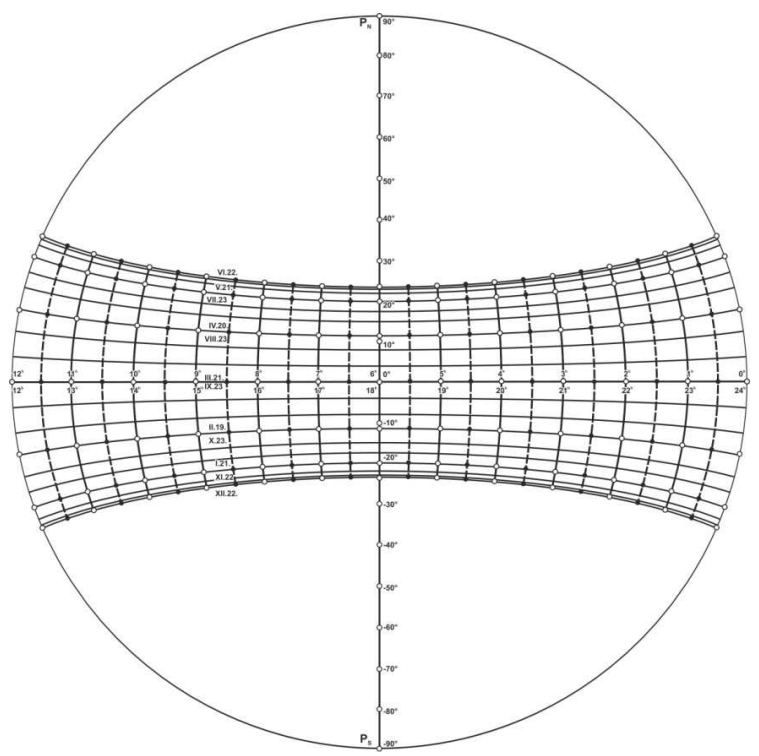

1. ábra. A Philippe de la Hire-féle vetület alapján készített forgatható korong felső rétege

A korong alsó rétege kartonból készült, körkörösen a peremén, továbbá a horizont mentén tartalmazza a szögskálákat, a szürke három sötétedő árnyalatával feltüntettük a szürkületi sávokat, rögzítettük a fö égtájak helyét, valamint a zenit és nadír pontokat. Az égbolt horizont fölötti, látható éggömbjének, ami megfelel a korong felső félkörlemezének, elhelyeztük horizontális koordináta-hálózatát 2,5-os sürüséggel La Hire-féle vetületben (2. ábra).

\begin{tabular}{|c|c|c||c|c|c||}
\hline \multirow{2}{*}{ Sorszám } & Dátum & Deklináció & Sorszám & Dátum & Deklináció \\
\hline \hline 1 & március 21. & $0^{\circ}$ & 19 & szeptember 23. & $0^{\circ}$ \\
\hline 2 & március 31. & $4^{\circ}$ & 20 & október 3. & $-4^{\circ}$ \\
\hline 3 & április 10. & $8^{\circ}$ & 21 & október 13. & $-8^{\circ}$ \\
\hline 4 & április 20. & $11,5^{\circ}$ & 22 & október 23. & $-11,5^{\circ}$ \\
\hline 5 & április 30. & $15^{\circ}$ & 23 & november 2. & $-15^{\circ}$ \\
\hline 6 & május 10. & $17,5^{\circ}$ & 24 & november 12. & $-17,5^{\circ}$ \\
\hline 7 & május 21. & $20^{\circ}$ & 25 & november 22. & $-20^{\circ}$ \\
\hline 8 & május 31. & $22^{\circ}$ & 26 & december 2. & $-22^{\circ}$ \\
\hline 9 & június 11. & $23^{\circ}$ & 27 & december 12. & $-23^{\circ}$ \\
\hline 10 & június 22. & $23,5^{\circ}$ & 28 & december 22. & $-23,5^{\circ}$ \\
\hline 11 & július 2. & $23^{\circ}$ & 29 & január 1. & $-23^{\circ}$ \\
\hline 12 & július 12. & $22^{\circ}$ & 30 & január 11. & $-22^{\circ}$ \\
\hline 13 & július 23. & $20^{\circ}$ & 31 & január 21. & $-20^{\circ}$ \\
\hline 14 & augusztus 3. & $17,5^{\circ}$ & 32 & január 31. & $-17,5^{\circ}$ \\
\hline 15 & augusztus 13. & $15^{\circ}$ & 33 & február 9. & $-15^{\circ}$ \\
\hline 16 & augusztus 23. & $11,5^{\circ}$ & 34 & február 19. & $-11,5^{\circ}$ \\
\hline 17 & szeptember 3. & $8^{\circ}$ & 35 & március 1. & $-8^{\circ}$ \\
\hline 18 & szeptember 13. & $4^{\circ}$ & 36 & március 11. & $-4^{\circ}$ \\
\hline \hline
\end{tabular}

1. táblázat. A Nap adatai az év folyamán

Az eszköz lényegében analóg módon épül fel azzal az ortografikus vetületi rendszeren (PÉNTEK (2010)) alapuló koronggal, amelyet PÉNTEK (2012) tanulmánya részletesen ismertet LÓSKAY (1904) korongja nyomán. Az ott részletezett módon megoldhatók a La Hire-vetületen alapuló eszközzel is az alapvető szférikus csillagászati alapfeladatok. Így 
könnyedén beállíthatjuk eszközünket a felhasználó helye földrajzi szélességének megfelelöen éppen úgy, mint egy univerzális asztrolábiumot. E beállítás után az év bármely napján megállapíthatjuk a Nap delelési magasságát és éjféli mélységét, a Nap kelési és nyugvási időpontját valódi napidőben, meghatározhatjuk a napkelte és napnyugta irányát, a nappal és az éjszaka időtartamát, továbbá a polgári, a navigációs és a csillagászati szürkület időtartamát is (3. ábra).
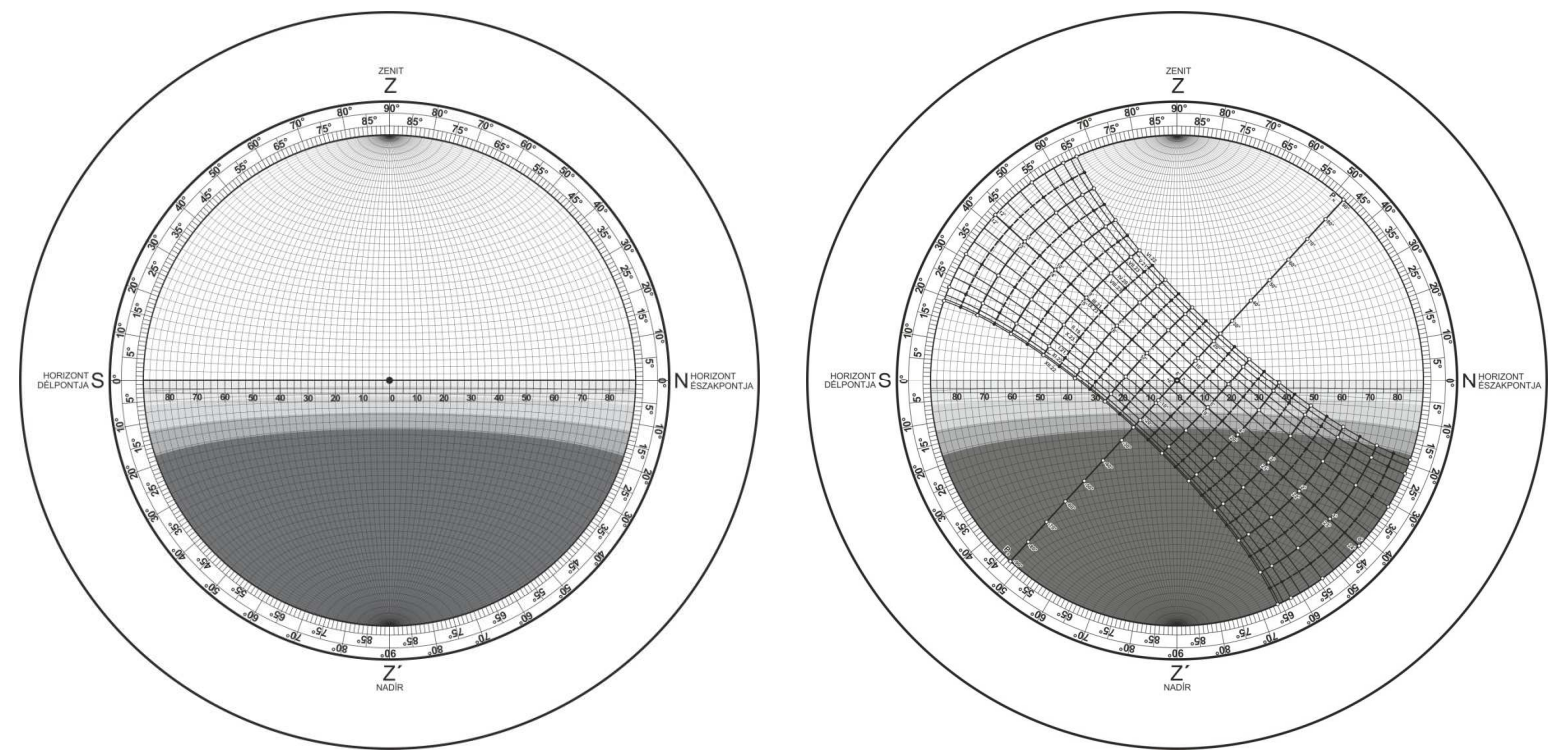

2. ábra. A Philippe de la Hire-féle vetuilet alapján készített forgatható korong (baloldalon csak az alsó rétege látható)

Ha a La Hire-féle vetületen alapuló korong hátoldalán kialakítunk egy egyszerü tengerészeti asztrolábiumot, akkor annak segítségével a korongot alkalmasan felfüggesztve meghatározhatjuk bármely időpontban a Nap horizont fölötti magasságát (4. ábra).

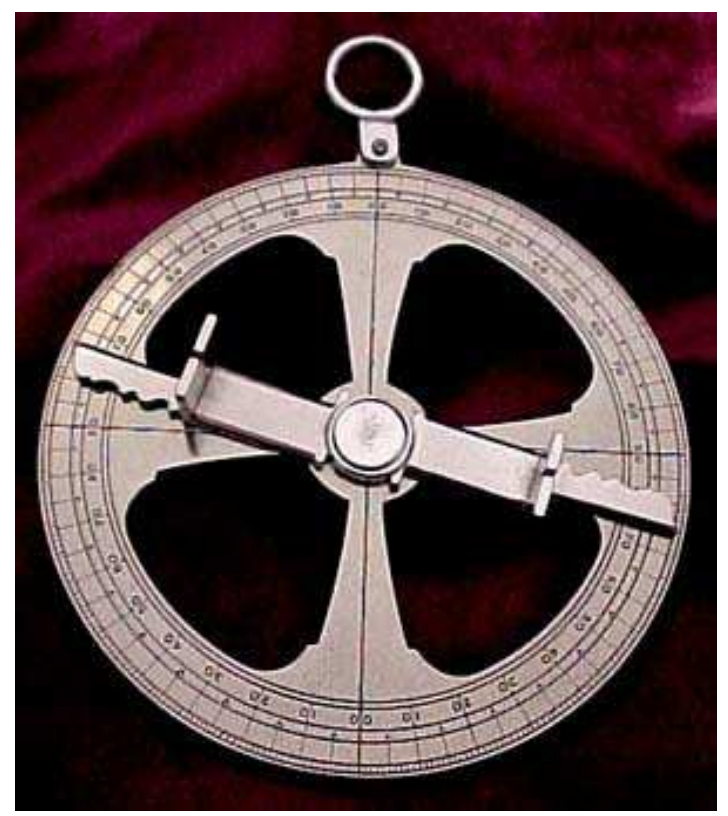

4. ábra. A tengerészeti asztrolábium 
Ismerve a dátumot, megkereshetjük a hozzátartozó Nappályát a korong első oldalán a vizsgált földrajzi hely szélességének megfelelően beállított átlátszó skálán. Keressük meg továbbá a korong alsó rétegén a lemért napmagasság ellipszis ívét. Határozzuk meg ezután e két görbe metszéspontját, s az átlátszó mozgó skála időbeosztásának megfelelően. E metszéspont szolgáltatja az adott időpillanathoz tartozó valódi napidőt (Bartha Lajos tudománytörténész szóbeli közlése).

Az adott hely földrajzi hosszúságát ismerve és felhasználva, továbbá az adott dátumhoz tartozó analemmáról leolvasott időkorrekció figyelembe vételével a valódi napidőből azonnal nyerhetjük a közép-európai zónaidőt, mint a hétköznapi életben használt polgári időt.

A La Hire vetületen alapuló korong ezen napóra üzemmódjára egy illusztráló feladatot mutatunk be. Szeptember 13-án a délutáni órákban $h=42,5^{\circ}$ Napmagasságot mérünk. Határozzuk meg a valódi napidőt, s ennek felhasználásával a közép-európai zónaidő értékét!

Szeptember 13-án a Nap deklinációja a I. táblázat felhasználásával $\delta_{\odot}=4^{\circ} . \mathrm{Az}$ analemma görbe felhasználásával az időegyenlítés értéke ekkor $E=+4^{m}$ (5. ábra).

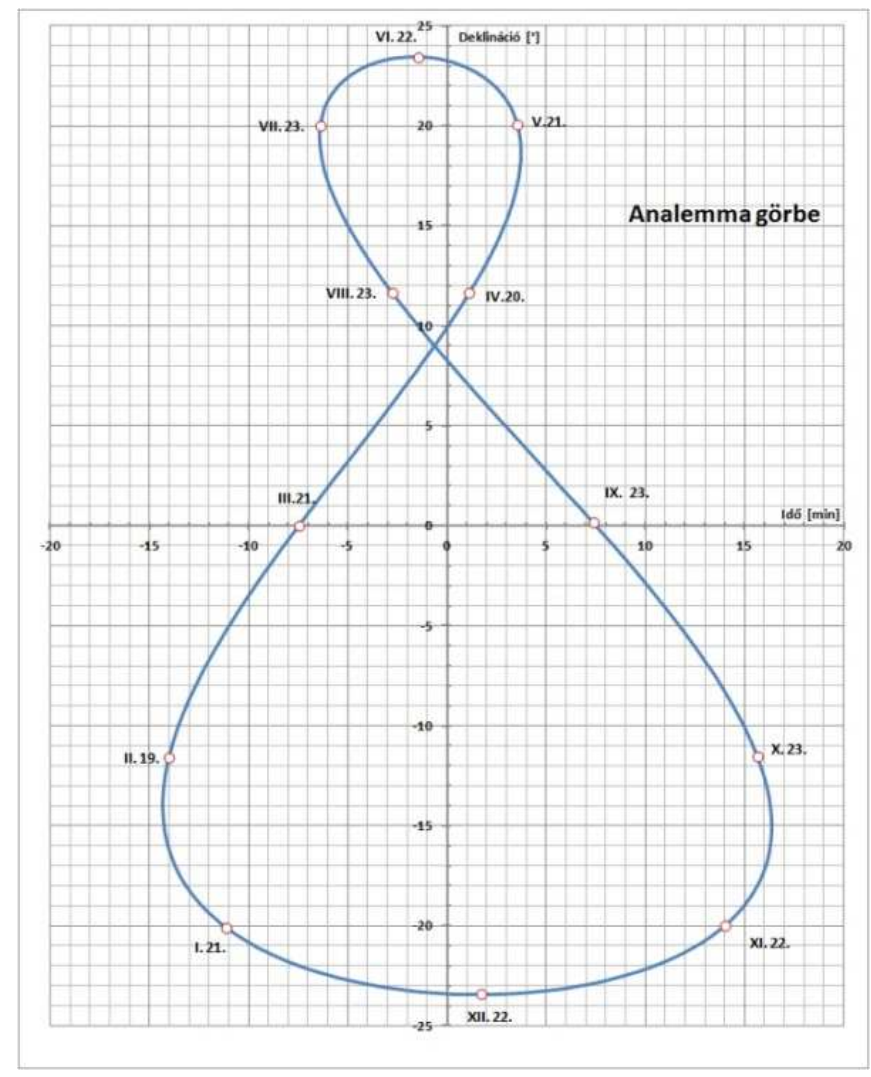

5. ábra: Az analemma görbe

Ha pl. Szombathelyen vagyunk, akkor a város földrajzi helyzete miatt $T_{\lambda}=+6,5^{m}$, hiszen időben kifejezve ennyire vagyunk keletre a közép-európai időzóna középvonalától (6. ábra).

Ezen ismeretek és adatok birtokában a korongról leolvasott valódi napidő értéke $T_{\odot}=13^{h} 30^{m}$, a közép-európai zónaidő $T$ értéke pedig a

$$
T=T_{\odot}-E-T_{\lambda}
$$

összefüggés felhasználásával

$$
T=13^{h} 30^{m}-4^{m}-6^{m} 30^{s}=13^{h} 19^{m} 30^{s} .
$$


Megjegyezzük, hogy lineáris interpolációt alkalmazva néhány perc pontossággal meghatározhatjuk a szóban forgó dátumhoz időben szomszédos kihúzott nappályák ismeretében a valódi napidő, vagy a közép-európai zónaidő értékét akkor is, ha a Nap aktuális deklinációjának megfelelő pályaív nem szerepel a korongon megszerkesztve.

A bemutatott példában felhasznált szférikus csillagászati fogalmak és összefüggések KÖVESLIGETHY (1899), MARIK (1989) és SZENKOVITS (2007) munkájában megtalálhatóak.

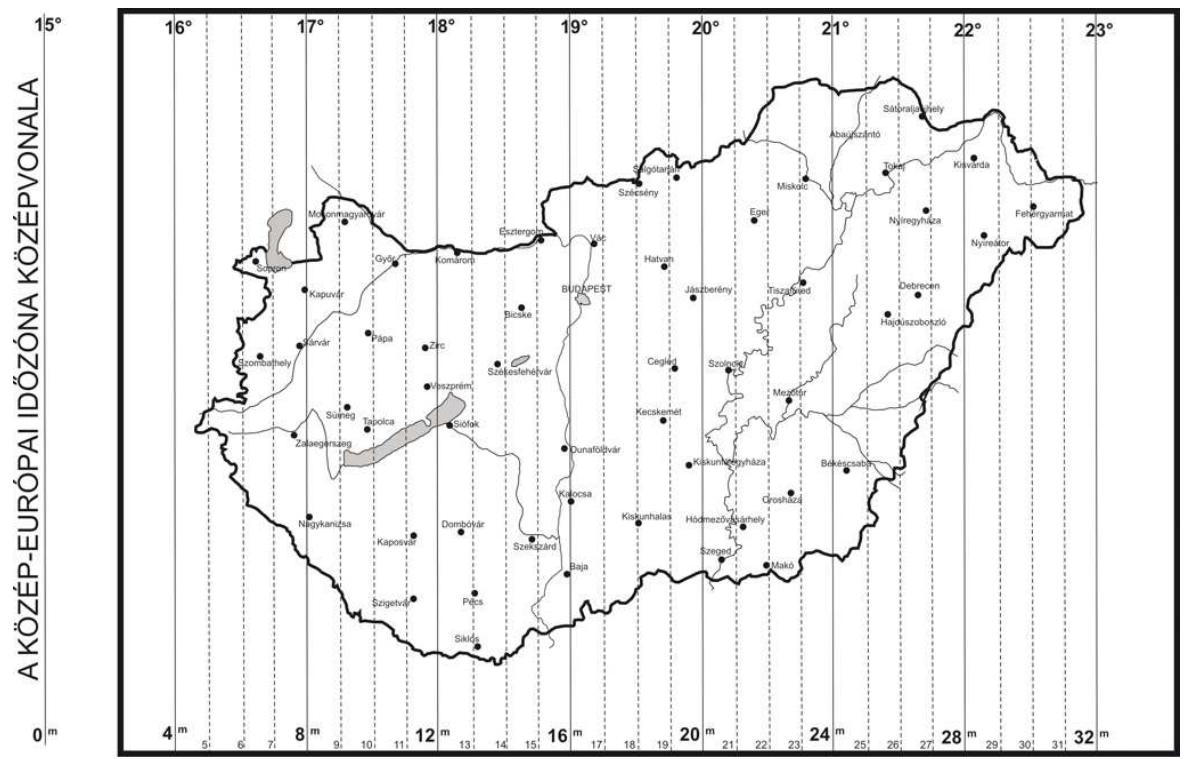

6. ábra: Térkép a földrajzi hely időkorrekciójának meghatározásához

\section{Alkalmazás: a Girasol, vagyis napraforgó}

Francia nyelvterületen (Centre de recherches methodologiques d'architecture de Nantes (CERMA)) az építészetben használnak egy olyan korong alakú eszközt, amely tetszőleges földrajzi szélességen, az év tetszőleges napjának tetszőleges órájában megmutatja a Nap azimutját és magasságát az égen. Erre azért van szükség, mert fontos az építészeti tervezésnél, hogy egymástól milyen távolságra és milyen tájolással kerüljenek az épületek, s lényeges kérdés, hogy milyen árnyékot vetnek egymásra és a környezetükre az év különbözö évszakjaiban és különböző napszakjaiban. A Nap pozíciójának meghatározásához használt eszköz lényegében egy speciálisan kialakított univerzális asztrolábium, amely sztereografikus egyenlítői vetületben jeleníti meg az éggömb horizont feletti tartományát és az év során a Nap által befutott égi pályákat (7. ábra).

Így tehát ez az eszköz a Gemma Frisius-féle univerzális asztrolábium lényeges részeinek megtartásával alakult ki. Az előző részben bemutatott Philippe de la Hire vetületén alapuló koronghoz hasonlóan képes a Nap helyzetét megmutatni, viszont skálái sajnos nem lineárisak, a készülék pereme felé ritkulnak. E korong nagy előnye viszont, hogy egyszerüen körzővel és vonalzóval, tehát euklideszi eszközökkel megszerkeszthető, míg a Philippe de la Hire-féle vetület ívei, mint láttuk, nehezebben előállítható ellipszis darabok. A Girasol müködéséröl további részletek HOLLANDER (1999) müvében olvashatók.

Az egyes korongokkal számos további probléma is tárgyalható és szemléltethető, ezek vizsgálatával a jövőben kívánunk foglalkozni. 


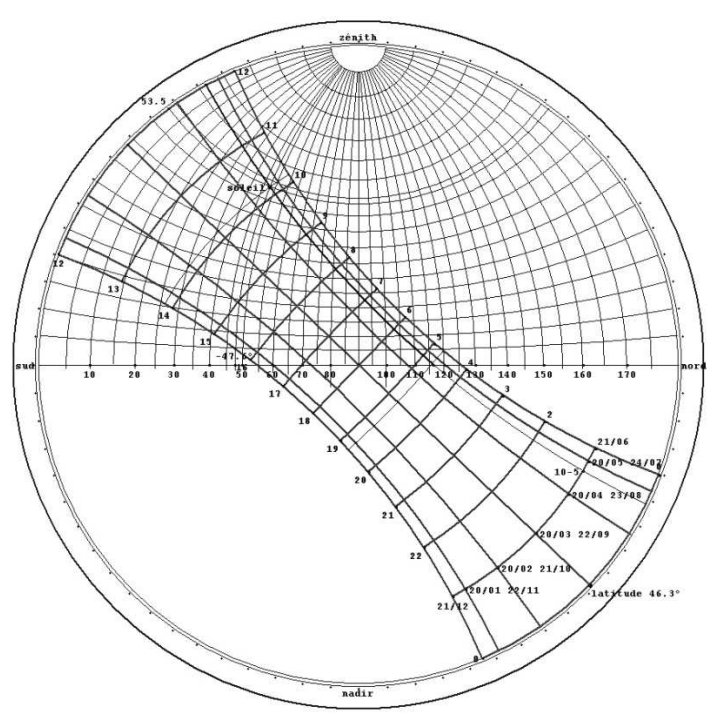

7. ábra. A Girasol, vagy napraforgó

\section{Köszönetnyilvánítás}

Hálás köszönet illeti meg Bartha Lajos tudománytörténészt a kézirat gondos átnézéséért és értékes tanácsaiért, megjegyzéseiért.

A szerző köszönetét fejezi ki továbbá Mitre Zoltánnak, a Gothard Amatőrcsillagászati Egyesület titkárának a Philippe de la Hire-féle korong gondos számítógépes megszerkesztéséért.

\section{Irodalomjegyzék}

[1] Hollander, R.: L’Astrolabe - Histoire, Théorie et Pratique, Institut Océanographique, Paris, (1999).

[2] Kövesligethy R.: A mathematikai és csillagászati földrajz kézikönyve, Kogutovicz és társa Magyar Földrajzi Intézete, Budapest, (1899).

[3] Lóskay M.: A Nap és a csillagok járása a Föld tetszőleges helyén, Magyar Földrajzi Intézet Rt. Budapest, (1904).

[4] Marik M.: Csillagászat. Akadémiai Kiadó, Budapest, (1989).

[5] Morrison, J. E.: The Astrolabe, Ed. Janus, Rehoboth Beach, DE, USA, (2010).

[6] Péntek K.: Ábrázoló geometriai módszerek alkalmazása a szférikus csillagászatban: az ortografikus meridián projekció, NymE SEK Tudományos Közleményei XVII. Természettudományok 12, Szombathely, (2010) 27-49.

[7] Péntek K.: Az ortografikus meridionális vetületi rendszeren alapuló csillagászati készülék: a Nap évi mozgását bemutató forgatható korong. NymE SEK Tudományos Közleményei XVIII. Természettudományok 13, Szombathely, (2012) 37-64.

[8] Péntek K.: Egy érdekes térképi vetület matematikai és csillagászati alkalmazásai, Dimenziók, Matematikai Közlemények II, Sopron, (2014) 3-8.

[9] Snyder, J. P. - Voxland, Ph. M.: An Album of Map Projections, U.S. Geological Survey Professional Paper 1453, Denver, (1989).

[10] Szenkovits F.: Bevezetés a csillagászatba. Kolozsvári Egyetemi Kiadó, Kolozsvár, (2007). 